\title{
Cytological quality of milk of primiparous cows kept in cubicles bedded with separated manure
}

\author{
Stanisław Winnicki ${ }^{1}$, Zbigniew Sobek ${ }^{2}$, Ryszard Kujawiak ${ }^{3}$, Jerzy Jugowar ${ }^{1}$, \\ Anna Nienartowicz-Zdrojewska ${ }^{2}$, and Jolanta Różańska-Zawieja ${ }^{2}$ \\ ${ }^{1}$ Institute of Technology and Life Sciences, Poznań Branch, ul. Biskupińska 67, 60-463 Poznań, Poland \\ ${ }^{2}$ Department of Genetics and Animal Breeding, Poznan University of Life Sciences, \\ ul. Wołyńska 33, 60-637 Poznań, Poland \\ ${ }^{3}$ Sano Agrar Institut, ul. Lipowa 10, 64-541 Sękowo, Poland \\ Correspondence to: Jolanta Różańska-Zawieja (jolek@up.poznan.pl)
}

Received: 30 May 2016 - Revised: 3 January 2017 - Accepted: 4 January 2017 - Published: 15 February 2017

\begin{abstract}
A study was conducted on the effect of separated manure as bedding material on milk quality as manifested in the somatic cell count. Cows were maintained in a loose barn in cubicles bedded with fresh separated cattle manure (SCM) with $40 \%$ solids content.

Analyses were conducted on 242 primiparous Polish Black and White Holstein-Friesian cows in the course of a 305-day lactation. Mean milk yield in that period amounted to over $9000 \mathrm{~kg}$ per cow. Somatic cell counts, daily milk yields and chemical composition of milk were analysed. Data were obtained from analyses of 2324 milk samples.

It was found that $93.3 \%$ of samples contained less than 400000 somatic cells per $1 \mathrm{~mL}$ milk. Approximately $4.3 \%$ of milk samples contained the number of somatic cells indicating subclinical mastitis (200 000 cells $\left.\mathrm{mL}^{-1}\right)$, while in $2.4 \%$ it was clinical mastitis $\left(>800000\right.$ cells mL $\mathrm{m}^{-1}$ ). The incidence rate for both forms of mastitis was similar in the beginning and at the end of lactation. Mean daily milk yield of cows producing milk classified according to quality (SCC) grades $1\left(<25000\right.$ cells mL $\left.\mathrm{mL}^{-1}\right)$ and $2(<25000$; $50000>$ cells $\mathrm{mL}^{-1}$ ) was statistically significantly greater than the yields of other cows. For analysed milk constituents a relationship was found between SCC classes and contents of milk fat and solids.

Conducted analyses showed that SCM as bedding in cow cubicles had no effect on somatic cell counts in milk of primiparous cows. The study was conducted in a single holding, in one lactation, on cows calving in 2014.
\end{abstract}

\section{Introduction}

A significant factor determining efficient milk production is connected with the health status of udders in dairy cows. Mastitis is one of the most frequent diseases in dairy cows and a major cause for their culling (Malinowski and Kłossowska, 2002; Engels, 2015; De Vliegher et al., 2005a). Mastitis is a condition of multiple etiology and its incidence is determined by both genetic and environmental factors. Among environmental factors, a considerable effect on udder hygiene is observed for bedding due to the direct contact with teats and the long lying time of cows in the $24 \mathrm{~h}$ period.

Two types of cubicle surface management are distinguished - bedding and floor management. A conventional solution is provided by cubicles with straw bedding. Farms with a large area of grassland and maize crops experience a shortage of straw for bedding. Sand, peat and sawdust are used as straw substitutes (Schrade et al., 2008). In recent years studies have been conducted on the suitability of conventional compost and compost produced from biogas plant digestate (Schrade et al., 2008) as well as Miscanthus chaff (Hohenbrink et al., 2013). Separated cattle manure, also referred to as dry manure solids (DMS), is currently being used as an alternative bedding material. Studies on its applicability have been conducted in the United States (Harrison et al., 2008; Schwarz et al., 2010), Germany and Switzerland (Leifker, 2013; Schlueter, 2012; Schrade et al., 2008; Son- 
theimer, 2011; Zaehner et al., 2009a, b). These analyses assessed the effect of DMS on the lying comfort of cows, cleanliness of their body, the incidence of limb skin damage, the presence of microorganisms in the bedding and in bulk milk, and labour outlays connected with bedding replacement. Results of those studies indicated no microbiological hazard for cows or milk connected with the use of DMS as bedding and showed no negative effect of such bedding on animal comfort. However, no studies were found in the available literature presenting an analysis of the effect of DMS bedding throughout lactation on the variation in SCC levels in milk collected from individual cows in the herd. For this reason it was decided to investigate the variation in somatic cell counts in milk from individual cows in the course of a standard 305day lactation. The proposed research hypothesis postulates that the application of DMS as bedding in individual cubicles may, after an extended period of time, result in an increased somatic cell count in milk and cause mastitis.

The aim of the study was to determine changes in SCC in milk of primiparous cows maintained in individual cubicles bedded with DMS during standard lactation.

\section{Material and methods}

Analyses were conducted based on productivity of primiparous cows in a herd of over 1000 cows. They were highproduction Black and White Polish Holstein-Friesian (PHF). This study did not require a permit to carry out experiments on animals. No tests were performed on animals, and the data for publication have been obtained from a nationwide computer system (SYMLEK) collecting data from routine performance inspection of dairy cows. In 2014, in the herd of 1170 cows, the mean milk yield was $12135 \mathrm{~kg}$ of milk per cow, with a mean of $3.66 \%$ fat and $3.33 \%$ protein. In view of these data this herd ranked second in Poland in the group of herds of over 500 cows (PFHBiPM Warszawa 2015). Cows, both during lactation and in the dry period, were kept in the free-stall system in individual cubicles (Fig. 1) bedded with separated cattle manure (SCM) coming from the farm (Fig. 2). Separated manure used as cubicle bedding contained $39-40 \%$ solids (manure before separation contained 7-8\% solids). Cow manure was removed from the barn alleys with a grooved solid floor six times a day using a delta scraper (Fig. 3).

The herd was fed with total mixed ration (TMR) in identical amounts for each cow in the entire herd in lactation. In the study period the composition of the feed ration was as follows: maize silage, $18 \mathrm{~kg}$; pressed sugar beet pulp, $10 \mathrm{~kg}$; grass silage, $6 \mathrm{~kg}$; molasses, $1 \mathrm{~kg}$; wheat straw, $0.8 \mathrm{~kg}$; and Lactasan concentrate, $9 \mathrm{~kg}$. The nutritive value of the feed ration was as follows: energy content 7.2 MJ net energy lactation, at $16.5 \%$ crude protein content. The feed ration was calculated for $36 \mathrm{~kg}$ of milk. TMR was administered twice daily and placed twice a day on the feeding table (Fig. 4).

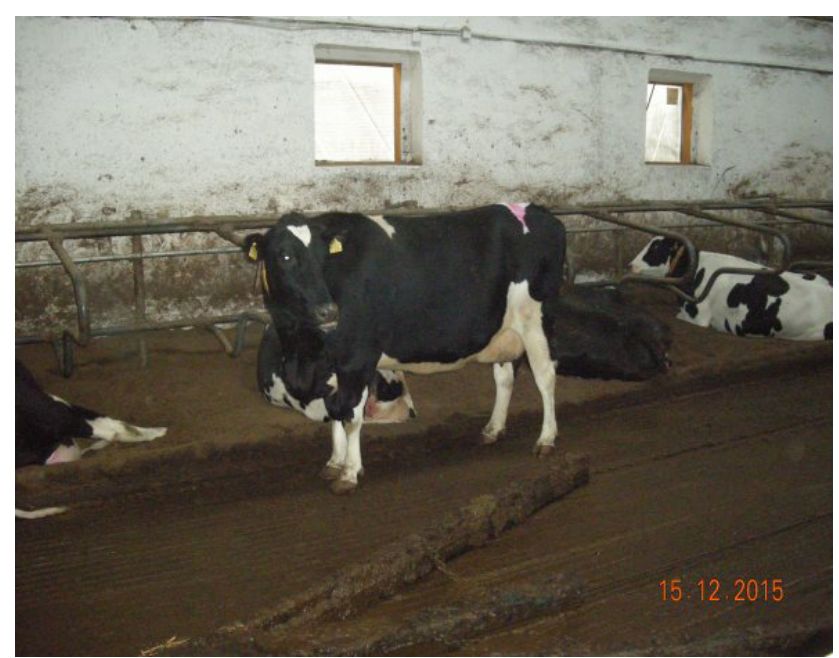

Figure 1. A cubicle bedded with DMS.

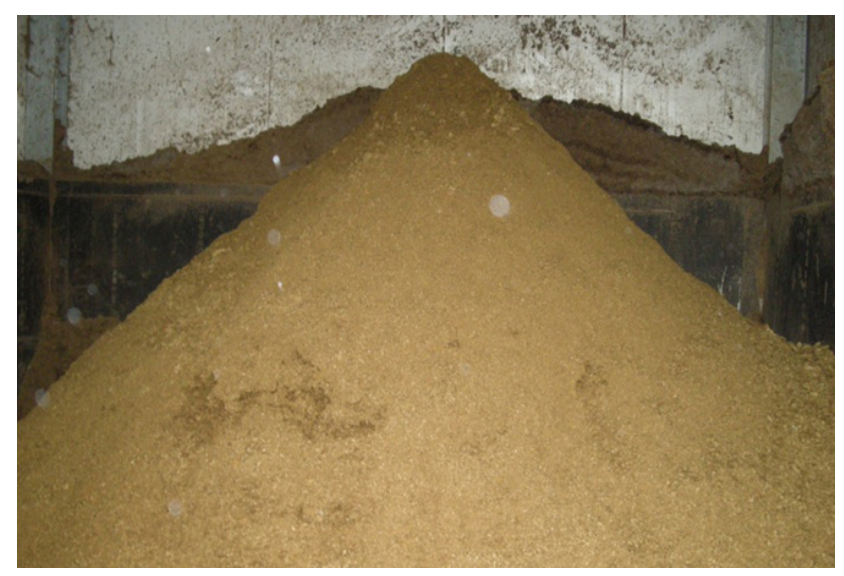

Figure 2. Separated manure (SM).

In the study period cows were milked three times a day in a 60-point carousel milking parlour with access to the udder outside of the carousel (Fig. 5). The farm is covered by the A4 milk recording system run by the Polish Federation of Cattle Breeders and Dairy Farmers (PFHBiPM).

Analyses were conducted on primiparous cows, which made it possible to standardise data and exclude several environmental factors. Analyses covered primiparous cows which calved between August 2013 and the end of February 2014.

Altogether data were collected for 242 primiparous cows during the period of a standard 305-day lactation. Analyses were conducted on milk recording data, i.e. quality expressed in SCC levels, daily milk yields and chemical composition in successive months of lactation. Statistical analyses were conducted using the SAS 9.2 (2009) statistical software package the MEAN, GLM and CORR procedures. Significance of differences between pairs of object means was tested using the least significant difference test. 


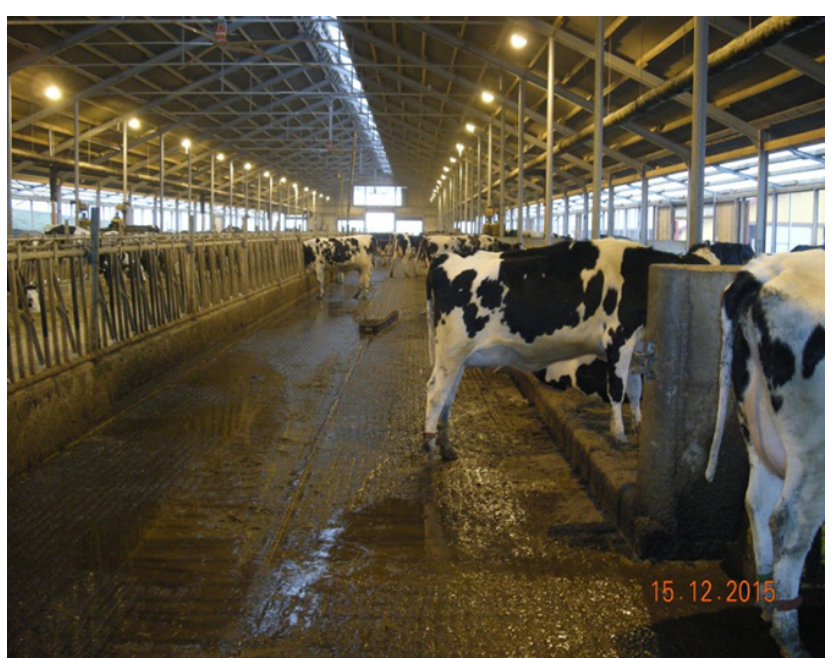

Figure 3. Grooved floor in alleys.

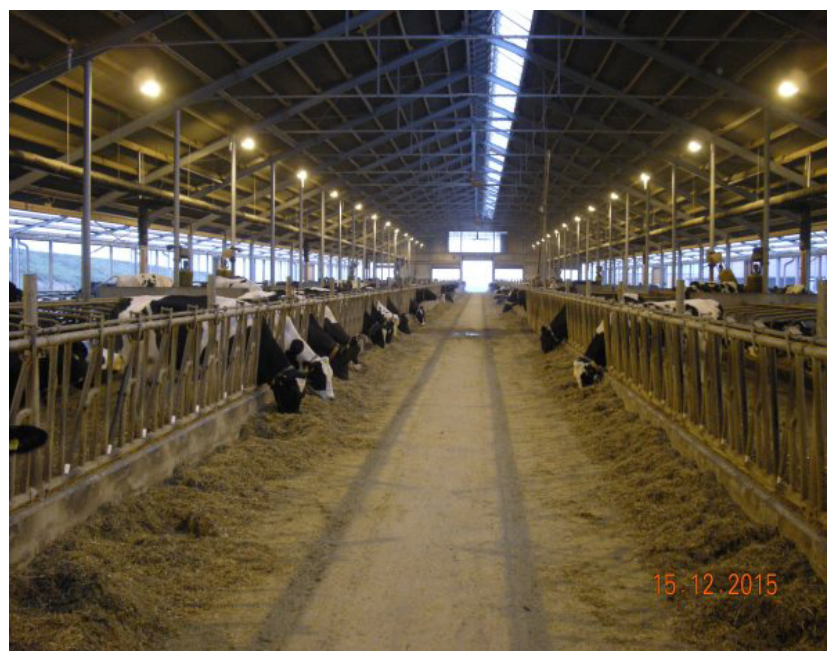

Figure 4. Feeding table.

\section{Results}

Mean daily milk yield in the herd in successive months of lactation was high and uniform (Table 1).

The lowest mean milk yield was recorded in the first month of lactation $(29.2 \mathrm{~kg})$; in the successive months it increased gradually, reaching the maximum in the fourth month $(38.4 \mathrm{~kg})$. Starting from the fifth month it decreased slightly. In the 10th month milk yield was $32.1 \mathrm{~kg}$ and it was $6.3 \mathrm{~kg}$ lower (by $16.4 \%$ ) than the maximum yield in the 4 th month of lactation.

The coefficient of variation was highest in the first month, amounting to $25.2 \%$. In the other months of lactation it ranged from 14.4 to $18.6 \%$ (Table 1).

Fat percentage content in milk was lowest at peak yield, in the 3rd and 4th months of lactation, after which it gradually increased to reach in $3.84 \%$ in the 10th month (Table 2).

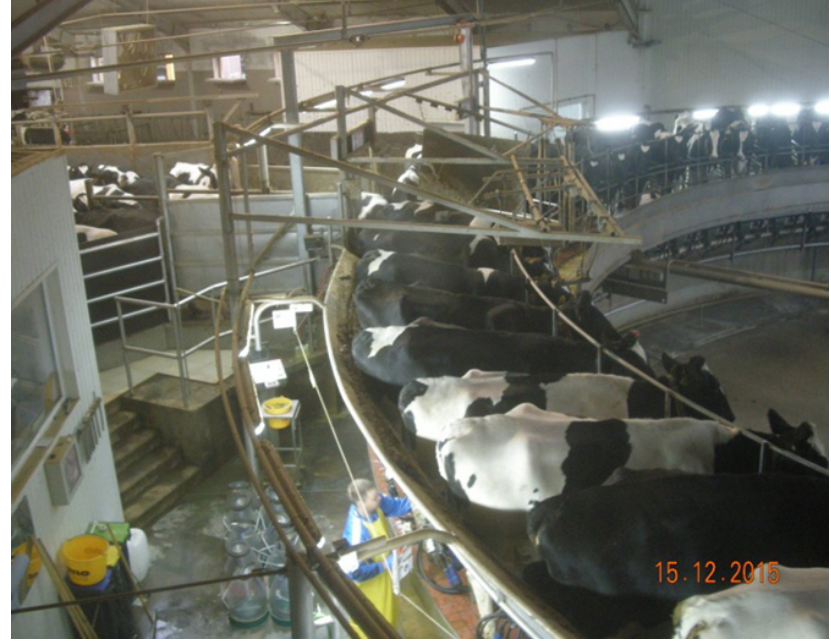

Figure 5. A 60-point carousel milking parlour.

Table 1. Milk yields of primiparous cows in the course of lactation.

\begin{tabular}{lrr|rr}
\hline & \multicolumn{2}{c|}{ Mean } & \multicolumn{2}{c}{ Daily milk yield } \\
\cline { 2 - 5 } $\begin{array}{l}\text { Month } \\
\text { of }\end{array}$ & $\begin{array}{r}\text { Mean } \\
\text { lactation }\end{array}$ & $\begin{array}{r}\text { \% to max } \bar{x} \\
\text { day yields }\end{array}$ & $\begin{array}{r}\text { Standard } \\
\text { deviation } \\
(\mathrm{kg})\end{array}$ & $\begin{array}{r}\text { Coefficient of } \\
\text { variation }\end{array}$ \\
\hline 1 & 29.2 & 75.9 & 7.35 & $(\%)$ \\
2 & 35.9 & 93.4 & 6.69 & 25.2 \\
3 & 38.0 & 98.9 & 5.80 & 18.6 \\
$\mathbf{4}$ & $\mathbf{3 8 . 4}$ & $\mathbf{1 0 0 . 0}$ & $\mathbf{5 . 5 3}$ & 15.3 \\
5 & 37.6 & 97.8 & 5.89 & $\mathbf{1 4 . 4}$ \\
6 & 36.0 & 93.9 & 6.08 & 15.7 \\
7 & 34.6 & 90.2 & 4.94 & 16.9 \\
8 & 34.2 & 89.0 & 5.44 & 14.3 \\
9 & 33.2 & 86.5 & 5.55 & 15.9 \\
10 & 32.1 & 83.6 & 5.96 & 16.7 \\
\hline
\end{tabular}

Mean protein content in milk was lowest in the 2nd month of lactation at $3.03 \%$ and it gradually increased to reach $3.5 \%$ in the 10 th month.

Mean lactose content in milk was relatively stable in the course of lactation (Table 1). We need to stress here the low individual variation, as indicated by the low value of the coefficient of variation, generally in the range from 2 to $3 \%$.

Contents of milk solids changed in the course of lactation. Except for the first month, when colostrum was produced, the lowest content of solids was observed at the beginning and it gradually increased in the course of lactation (Table 2). Individual variation was small, as the coefficient of variation was generally around $5 \%$.

Mean urea content in milk in the months of lactation was similar, ranging from 210 to $243 \mathrm{~mL}$ (Table 2). In turn, considerable individual variation was found, as the coefficient of variation as a rule exceeded $15 \%$ and in the second month of lactation it even exceeded $25 \%$. 
Table 2. Changes in chemical composition in milk of primiparous cows in the course of lactation.

\begin{tabular}{|c|c|c|c|c|c|c|c|c|c|c|}
\hline \multirow{3}{*}{$\begin{array}{l}\text { Month } \\
\text { of } \\
\text { lactation }\end{array}$} & \multicolumn{10}{|c|}{ Contents in milk } \\
\hline & \multicolumn{2}{|c|}{$\begin{array}{l}\text { Fat } \\
(\%)\end{array}$} & \multicolumn{2}{|c|}{$\begin{array}{c}\text { Protein } \\
(\%)\end{array}$} & \multicolumn{2}{|c|}{$\begin{array}{c}\text { Lactose } \\
(\%)\end{array}$} & \multicolumn{2}{|c|}{$\begin{array}{c}\text { Solids } \\
(\%)\end{array}$} & \multicolumn{2}{|c|}{$\begin{array}{c}\text { Urea } \\
\left(\mathrm{mg} \mathrm{mL}^{-1}\right)\end{array}$} \\
\hline & $\bar{x}^{*}$ & $\mathrm{SD}^{* *}$ & $\bar{x}$ & SD & $\bar{x}$ & SD & $\bar{x}$ & SD & $\bar{x}$ & SD \\
\hline 1 & 4.37 & 0.70 & 3.24 & 0.29 & 4.89 & 0.17 & 13.12 & 0.90 & 220 & 48 \\
\hline 2 & 3.44 & 0.57 & 3.03 & 0.19 & 4.98 & 0.11 & 11.97 & 0.67 & 210 & 54 \\
\hline 3 & 3.33 & 0.48 & 3.07 & 0.19 & 4.96 & 0.10 & 11.89 & 0.61 & 216 & 45 \\
\hline 4 & 3.37 & 0.48 & 3.16 & 0.21 & 4.94 & 0.11 & 12.00 & 0.63 & 227 & 45 \\
\hline 5 & 3.44 & 0.47 & 3.19 & 0.20 & 4.92 & 0.11 & 12.09 & 0.59 & 227 & 43 \\
\hline 6 & 3.56 & 0.48 & 3.25 & 0.22 & 4.87 & 0.13 & 12.25 & 0.62 & 238 & 36 \\
\hline 7 & 3.69 & 0.45 & 3.33 & 0.23 & 4.87 & 0.12 & 12.48 & 0.64 & 243 & 34 \\
\hline 8 & 3.73 & 0.45 & 3.36 & 0.23 & 4.85 & 0.14 & 12.57 & 0.59 & 235 & 40 \\
\hline 9 & 3.72 & 0.44 & 3.41 & 0.27 & 4.86 & 0.15 & 12.64 & 0.64 & 242 & 39 \\
\hline 10 & 3.84 & 0.45 & 3.50 & 0.22 & 4.88 & 0.13 & 12.86 & 0.62 & 241 & 33 \\
\hline
\end{tabular}

$* \bar{x}$ - mean. ${ }^{* *} \mathrm{SD}-$ standard deviation.

Table 3 presents the distribution of milk samples in terms of milk quality expressed in SCC levels in the course of lactation. Percentage of individual quality classes changed in the successive months of lactation.

The primary direction of changes was found for the decrease in percentages of samples in classes 1 and 2 and the increase in classes 4 and 5 in successive months of lactation. The percentage of milk samples in the first SCC class up to mid-lactation exceeded $10 \%$. In turn, in the second half of lactation it gradually decreased, while in the 10th month of lactation it was as low as $3.5 \%$.

In SCC class 2 at the beginning of lactation there were 33$35 \%$ milk samples, in mid-lactation it was $22-27 \%$, while at the end of lactation it was approximate $18 \%$.

In SCC class 3 the percentage of milk samples was relatively stable in the course of the entire lactation. It was also considerable, ranging from 28 to $34 \%$.

The share of milk samples in class 4 at the beginning of lactation was over $10 \%$, while at the end of lactation it increased considerably to $25 \%$. The share of milk samples in class 5 also grew considerably, from approximate $5 \%$ at the beginning to $12 \%$ at the end of lactation.

The percentage of milk samples in class 6 was relatively low, from $1.7 \%$ in the second month to $5 \%$ in the eight month, and only twice did it exceed $6 \%$. Relatively few milk samples were found in class 7 , and in the third month there were no samples of that SCC class.

The modal value typically exceeded $30 \%$ milk samples and it was found in SCC classes 2 and 3 -in the first 3 months in class 2 and from the 4th to the 10th month of lactation in class 3 .

Statistical analysis to identify correlations between SCC class of milk and milk yield (Table 4) and its chemical composition was conducted (Tables 5 and 6).
The highest daily milk yield was recorded for cows producing milk classified to SCC classes 1 and 2 . The difference between yields in these classes proved to be statistically nonsignificant. Differences in milk yield between classes from 3 to 7 also turned out to be statistically non-significant. In turn, differences between classes 1 and 2 and the others were statistically highly significant.

Mean percentage shares of fat, protein, lactose and solids as well as the weight content of urea in samples of milk classified to individual SCC classes varied for individual components.

For protein, lactose and urea, differences between classes proved to be statistically non-significant.

Statistical differences were observed for fat and milk solids (Table 5). Fat content gradually increased from $3.42 \%$ in class 1 , to $3.85 \%$ in class 6 , while only in class 7 did it decrease to $3.72 \%$ (Table 5).

In the case of milk solids the lowest content was also reported in SCC class 1 at $12.11 \%$, while it was highest in class 2 at $12.77 \%$ (Table 5). Differences between these classes with extreme values and the other classes were statistically highly significant.

\section{Discussion}

Milk yield of primiparous cows in the analysed herd was much greater both in comparison to the mean yield in the Wielkopolskie province, in which this herd is kept, and in comparison to the national average (Table 6). This refers to both the first 100 days of lactation $(643$ and $786 \mathrm{~kg}$ greater, respectively) and the entire period of 305-day lactation (1593 and $2130 \mathrm{~kg}$ greater, respectively).

We need to stress here two advantageous factors characterising the course of lactation: a long period of yield increase, to the 4th month of lactation, and the long-term persistent 
Table 3. Distribution of milk samples in terms of SCC classes in months of lactation.

\begin{tabular}{|c|c|c|c|c|c|c|c|c|c|c|c|}
\hline \multirow{2}{*}{$\begin{array}{l}\text { Milk } \\
\text { SCC } \\
\text { class }\end{array}$} & \multirow{2}{*}{$\begin{array}{r}\text { Somatic } \\
\text { cell count } \\
\text { (thousand } \mathrm{mL} \text { ) }\end{array}$} & \multicolumn{10}{|c|}{ Percentage of milk samples in months of lactation } \\
\hline & & 1 & 2 & 3 & 4 & 5 & 6 & 7 & 8 & 9 & 10 \\
\hline 1 & $\leq 25$ & 8.5 & 12.7 & 11.9 & 14.3 & 11.1 & 6.9 & 6.1 & 6.2 & 4.7 & 3.5 \\
\hline 2 & $\leq 50$ & $33.8^{*}$ & 34.3 & 35.2 & 27.3 & 25.3 & 22.5 & 19.2 & 18.6 & 18.3 & 18.9 \\
\hline 3 & $\leq 100$ & 26.9 & 31.4 & 28.0 & 34.1 & 30.9 & 30.3 & 27.9 & 33.5 & 28.6 & 33.3 \\
\hline 4 & $\leq 200$ & 16.9 & 12.7 & 17.4 & 12.6 & 16.6 & 22.1 & 24.0 & 21.5 & 27.7 & 25.0 \\
\hline 5 & $\leq 400$ & 7.5 & 5.1 & 4.7 & 7.1 & 10.6 & 10.8 & 11.4 & 11.6 & 11.3 & 12.7 \\
\hline 6 & $\leq 800$ & 4.0 & 1.7 & 2.8 & 2.1 & 4.1 & 4.8 & 6.6 & 5.0 & 6.1 & 4.8 \\
\hline 7 & $>800$ & 2.4 & 2.1 & 0.0 & 2.5 & 1.4 & 2.6 & 4.8 & 3.6 & 3.3 & 1.8 \\
\hline
\end{tabular}

* Bold - maximum number of observations in the SCC class.

Table 4. Distribution of milk samples in SCC classes and daily milk yield.

\begin{tabular}{|c|c|c|c|c|c|c|}
\hline \multirow[b]{2}{*}{$\begin{array}{l}\text { Milk } \\
\text { SCC } \\
\text { class }\end{array}$} & \multirow[b]{2}{*}{$\begin{array}{r}\text { Somatic } \\
\text { cell count } \\
\text { (thousand } \mathrm{mL} \text { ) }\end{array}$} & \multicolumn{2}{|c|}{$\begin{array}{l}\text { Frequency of } \\
\text { observations }\end{array}$} & \multicolumn{3}{|c|}{ Daily milk yield } \\
\hline & & $n$ & $\%$ & $\begin{array}{r}\text { Mean } \\
\bar{x} \\
(\mathrm{~kg})\end{array}$ & $\begin{array}{r}\text { \% to } \max \\
\bar{x} \\
\text { (daily yields) }\end{array}$ & $\begin{array}{r}\text { Standard } \\
\text { deviation } \\
\text { (SD) }\end{array}$ \\
\hline 1 & $\leq 25$ & 196 & 8.4 & $36.5^{\mathrm{A} * * *}$ & 100.0 & 5.93 \\
\hline 2 & $\leq 50$ & 588 & 25.3 & $35.6^{\mathrm{A}}$ & 97.3 & 6.56 \\
\hline 3 & $\leq 100$ & 709 & 30.6 & $34.6^{\mathrm{B}}$ & 94.7 & 6.74 \\
\hline 4 & $\leq 200$ & 461 & 19.8 & $34.7^{\mathrm{B}}$ & 94.9 & 6.82 \\
\hline 5 & $\leq 400$ & 213 & 9.2 & $33.7^{\mathrm{B}}$ & 92.1 & 6.64 \\
\hline 6 & $\leq 800$ & 101 & 4.3 & $34.2^{\mathrm{B}}$ & 93.7 & 6.29 \\
\hline 7 & $>800$ & 56 & 2.4 & $33.1^{\mathrm{B}}$ & 90.5 & 7.35 \\
\hline
\end{tabular}

*** Means marked with identical letters are not significantly different. Capital letters (A, B, C) - highly statistically significant differences $(P \leq 0.01)$.

milk production; in the 10th month mean daily yield was $32.1 \mathrm{~kg}$, which accounts for $83.6 \%$ in relation to maximum production (Table 1). The decisive cause for the very gentle decrease in the amount of obtained milk was connected with intensive feeding, particularly in the second part of lactation.

High variation in yield in the first month of lactation resulted from the conditions under which it was determined. On milk recording days for cows in the herd, the number of days which passed from the beginning of lactation varied for individual cows, and thus they were at different levels of milking. It also refers to the second month of lactation. In turn, a greater coefficient of variation in milk yield in the 10th month of lactation $(18.6 \%)$ was the effect of the final phase of lactation for several cows. An increase in fat contents in milk in the course of lactation is a natural physiological process. Such a character of changes was observed in both the analysed herd and nationwide (Table 6).

Protein content in milk indicates the degree of balance between yield and energy intake with feed (Ziemiński and Juszczak, 1997). At the state of balance the content of protein should fall between 3.2 and $3.6 \%$. It is relatively difficult to provide energy with feed at a high yield at peak lactation. Thus, it is believed that a $3.1 \%$ protein content is a minimum value.

In the analysed primiparous cows in the second and third months of lactation the mean value was lower, i.e. 3.03 and $3.07 \%$, respectively, thus indicating a negative energy balance of the diet in relation to yields (Table 2). In the fourth and fifth months of lactation the content of protein was also too low, and only starting from the 6th month did it meet the standard guidelines. In that period the daily yield of milk exceeded the energy value of the feed ration calculated for $36 \mathrm{~kg}$ milk. Starting from the sixth month of lactation, the daily yield was on average max. $36 \mathrm{~kg}$. In that period the content of protein in milk was within the normal limits.

Among all milk components the content of lactose in milk from healthy cows was characterised by high stability. This results from its important role in providing electrolyte balance in the process of milk synthesis in the udder. At mastitis lactose content decreases at a simultaneous increase in the content of chlorine. Recorded data indicate that udders of analysed primiparous cows were generally healthy. 
Table 5. Chemical composition of milk depending on SCC class.

\begin{tabular}{|c|c|c|c|c|c|c|c|c|c|c|c|}
\hline \multirow{3}{*}{$\begin{array}{l}\text { Month } \\
\text { of } \\
\text { lactation }\end{array}$} & & \multicolumn{10}{|c|}{ Contents in milk } \\
\hline & & \multicolumn{2}{|c|}{$\begin{array}{l}\text { Fat } \\
(\%)\end{array}$} & \multicolumn{2}{|c|}{$\begin{array}{c}\text { Protein } \\
(\%)\end{array}$} & \multicolumn{2}{|c|}{$\begin{array}{c}\text { Lactose } \\
(\%)\end{array}$} & \multicolumn{2}{|l|}{$\begin{array}{c}\text { Solids } \\
(\%)\end{array}$} & \multicolumn{2}{|c|}{$\begin{array}{c}\text { Urea } \\
\left(\mathrm{mg} \mathrm{mL}^{-1}\right)\end{array}$} \\
\hline & & $\bar{x}^{*}$ & $\mathrm{SD}^{* *}$ & $\bar{x}$ & SD & $\bar{x}$ & SD & $\bar{x}$ & SD & $\bar{x}$ & SD \\
\hline 1 & $\leq 25$ & $3.42^{\mathrm{A} * * *}$ & 0.60 & 3.18 & 0.22 & 4.98 & 0.11 & $12.11^{\mathrm{Aa}}$ & 0.76 & 227 & 48.4 \\
\hline 2 & $\leq 50$ & $3.57^{\mathrm{BC}}$ & 0.62 & 3.25 & 0.24 & 4.94 & 0.17 & $12.77^{\mathrm{BC}}$ & 0.77 & 227 & 43.8 \\
\hline 3 & $\leq 100$ & $3.67^{\mathrm{B} \mathrm{E}}$ & 0.60 & 3.37 & 0.28 & 4.98 & 0.17 & $12.44^{\mathrm{BDE}}$ & 0.77 & 230 & 44.7 \\
\hline 4 & $\leq 200$ & $3.67^{\mathrm{B} \mathrm{E}}$ & 0.54 & 3.29 & 0.26 & 4.87 & 0.13 & $12.44^{\mathrm{BD} g}$ & 0.71 & 234 & 42.7 \\
\hline 5 & $\leq 400$ & $3.75^{\mathrm{BD}}$ & 0.65 & 3.33 & 0.28 & 4.84 & 0.15 & $12.52^{\mathrm{BD}}$ & 0.78 & 232 & 41.9 \\
\hline 6 & $\leq 800$ & $3.85^{\mathrm{BDF}}$ & 0.54 & 3.35 & 0.25 & 4.82 & 0.16 & $12.64^{\text {BDFhi }}$ & 0.68 & 232 & 35.9 \\
\hline 7 & $>800$ & $3.72^{\mathrm{B}}$ & 0.54 & 3.26 & 0.23 & 4.77 & 0.13 & $12.36^{\mathrm{bD} \mathrm{j}}$ & 0.59 & 232 & 44.1 \\
\hline
\end{tabular}

Table 6. Yield of primiparous cows in the analysed herd in the province of Wielkopolskie and nationwide in 2014.

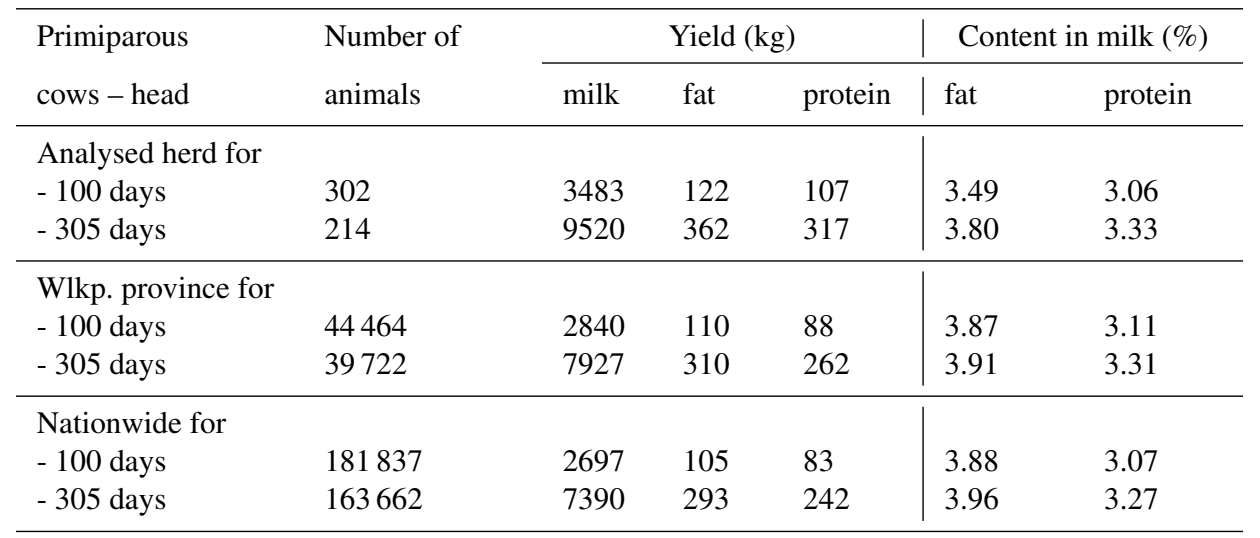

An increase in solids content in successive months of lactation is a natural phenomenon observed due to the increase in the contents of fat and protein in milk.

Mean urea content in milk throughout lactation fell within the limits specified by Ziemiński and Juszczak (1997). Relatively uniform values in the course of lactation were determined by the stable composition of the feed ration.

The primary indicator for hygienic quality of milk is connected with the quality expressed by the somatic cell count (SCC). In Poland, similar to in many other countries, the upper SCC limit for liquid milk for human consumption is assumed to be $400000 \mathrm{~mL}$, which is a threshold value in Poland in milk buying (Regulation of the Minister of Agriculture and Rural Development, Journal of Laws no. 117, item 1011). Milk in classes 1-5 contains the number of somatic cells admissible for commercial sale. In the analysed herd there were a total of $93.3 \%$ individual milk samples in these classes (Table 2) with relatively small deviations for individual months of lactation (Table 3). An elevated SCC value indicates the incidence of mastitis. An SCC level above $400000 \mathrm{~mL}$ in- dicates subclinical mastitis, while the level of over 800000 shows clinical mastitis. In the analysed herd, mastitis was found in the course of entire lactation with a similar, low frequency in individual months of lactation (Table 3).

Mastitis in primiparous cows in the subclinical and clinical forms was already observed in the first month of lactation, at 4 and $2.4 \%$, respectively (Table 4 ). These cases may not have been caused by the use of DMS as bedding in cubicles, but rather an earlier effect of other factors. Parker et al. (2007) and Malinowski and Smulski (2007) indicate frequent mastitis cases already in primiparous cows. For this reason they recommend diagnostics and treatment of udders in heifers before calving. A comparable frequency of mastitis in primiparous cows in the analysed herd in the course of entire lactation indicates that DMS bedding in cubicles was not a source of mastitis hazard (Table 4).

Statistical analysis was conducted on differences in daily milk yields (Table 5) and milk chemical composition in SCC classes (Tables 6-8). The highest milk yield was obtained from cows from SCC classes 1 and 2, i.e. 36.5 
and $35.6 \mathrm{~kg} \mathrm{day}^{-1}$ (Table 4). The difference between these classes proved to be statistically non-significant. The same statement was given in a report by the American National Mastitis Council (Laboratory and Field, 1987) and it was confirmed in a study by De Vliegher et al. (2005b). Differences in milk yield between SCC classes 1 and 2 and the others, i.e. from 3 to 7 , proved to be statistically highly significantly. These differences are relatively slight; however, they indicate a deterioration of milk production functions of the udder.

The Laboratory and Field (1987) report showed that, starting from SCC class 3, milk yield decreases by $1.5 \mathrm{lb}$ (approx. $0.7 \mathrm{~kg}$ ) a day for each class. In our study no such uniform decrease was recorded. This incomplete consistency with data contained in the Laboratory and Field (1987) report results from the fact that this study concerns only one barn and for this reason it may not lead to generalisations.

A slightly different method was adopted by De Vliegher et al. (2005b), who determined SCC in primiparous cows between the 5th and 14th day of lactation. They stated that mastitis in that period causes a decrease in yield for the entire lactation.

The chemical composition of milk depends on nutrition and milk production functions of the udder. Protein content in milk is determined by the supply of energy and urea content from the supply of protein in feed (Ziemiński and Juszczak, 1997). Lactose content in milk is connected with the maintenance of osmotic pressure and it is regulated in the process of milk production. Fat content is determined by hereditary factors and nutrition, mainly fibre contents in feed.

In the analysed herd of primiparous cows contents of protein, lactose and urea were similar in SCC classes. Statistically significant differences were found only for contents of fat and solids (Table 5). The higher the SCC class, the greater the content of fat. There exists a relationship between milk yield and fat content - the higher the yield, the lower the fat percentage. In turn, for milk solids the lowest contents were found in SCC class 1, while it was highest for class 2. Such a situation is connected with the lowest contents of fat and protein in milk of cows in SCC class 1.

Changes in the chemical composition of milk, in classes from 1 to 6 , were not the effect of SCC, but they were determined by dependencies between the daily yield of milk and contents of fat and protein. Recorded results indicate that at subclinical mastitis in SCC class 6 the milk production functions were not disturbed. Only at clinical mastitis in group 7 functional changes were found in milk synthesis. This is evidenced by lower contents of fat, protein and lactose in relation of group 6.

Recorded results show that the cubicle management of primiparous cows with high milk yields caused no deterioration of SCC quality of milk in the course of a standard 305day lactation. Providing high comfort for cows when lying is the reason for a search for new bedding materials. Although they are many very good mats and mattresses for cubicles,

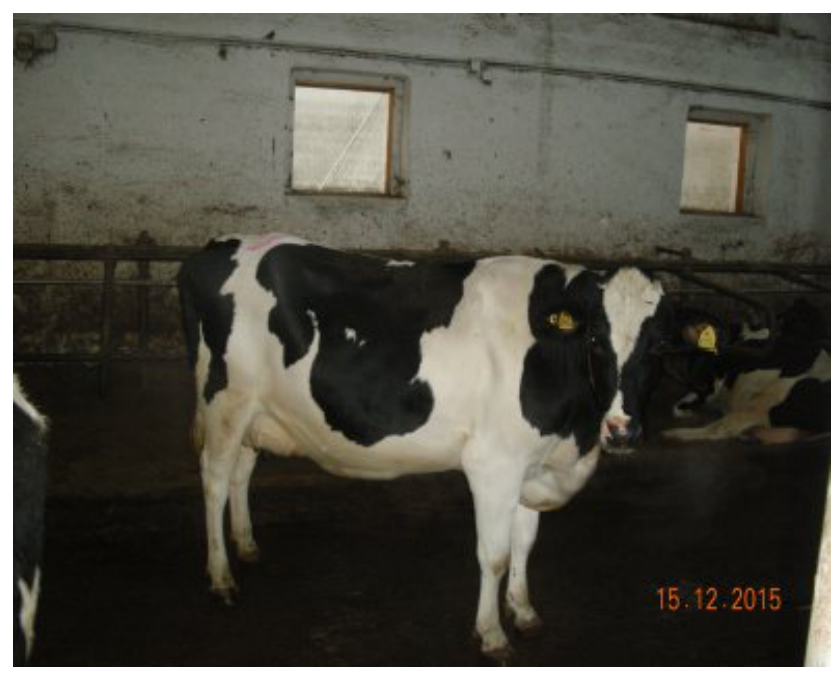

Figure 6. A clean cow standing on separated manure.

they are inferior to bedding, particularly in terms of protection of body surface (Schaub et al., 1999). In comparison to mattresses, DMS bedding is considerably more effective in prevention of skin lesions (Schrade et al., 2008). This was confirmed in the analysed herd. Cows are clean and no skin damage or lesions are observed (Fig. 6). Another advantage of DMS bedding is connected with its resilience and adaptability to the body contours of the lying animal. This may even be a certain problem, since humps are easily formed in the cubicle. For this reason manual levelling of bedding in the cubicle is required.

\section{Conclusions}

Analyses were conducted on high-production primiparous cows kept in cubicles bedded with separated cattle manure showed the following:

- DMS may successfully be used, with no deterioration of SCC milk quality, as bedding material in resting pens for dairy cows in well-managed (high-production) herds.

- The highest milk yield was recorded for cows with SCC levels below $50000 \mathrm{~mL}^{-1}$. Their yields were statistically significantly greater in comparison to higher SCC classes.

\section{Animal Welfare Statement}

This study did not require a permit to carry out experiments on animals. No tests were performed on animals, and the data for publication have been obtained from a nationwide computer system SYMLEK collecting data from routine performance inspection of dairy cows. 


\section{Data availability}

The data used in this paper can be found in the Supplement.

\section{The Supplement related to this article is available online at doi:10.5194/aab-60-19-2017-supplement.}

Competing interests. The authors declare that they have no conflict of interest.

Edited by: M. Mielenz

Reviewed by: M. Schwarz and one anonymous referee

\section{References}

De Vliegher, S., Barkema, H. W., Opsomer, G., de Kruif, A., and Duchatau, L.: Association Between Somatic Cell Count in Early Lactation and Culling of Dairy Heifers Using Cox Frailty Models, J. Dairy Sci., 88, 560-568, 2005a.

De Vliegher, S., Barkema, H. W., Stryhn, H., Opsomer, G., and de Kruif, A.: Impact of Early Lactation Somatic Cell Count in Heifers on Milk Yield Over the First Lactation, J. Dairy Sci., 88, 938-947, 2005b.

Engels, H.: To save money, DLG, Special Releases, 10-13, 2015.

Harrison, E., Bonhotal, J., Schwarz, M., and Fiesinger, T.: Using Manure Solid as Bedding, Final Raport, Cornell Waste Management Institute, 2008.

Hohenbrink, S., Boelhauve, M., Fiege, F., and Ickler, A. L.: Sprinkle grass in the pit - elephants, Top Agrar, 10, 14-17, 2013.

Laboratory and Field: Handbook on Bovine mastitis: National Mastitis Council USA, Library of Congress Catalog Number 87081736, 1987.

Leifker, A.: „Gülle-Einstreu“: Bleiben die Euter gesund?, Top Agrar, 3, 20-23, 2013.
Malinowski, E. and Kłossowska, A.: Diagnostic of infection and mastitis, Puławy National Veterinary Research Institute, 2002.

Malinowski, E. and Smulski, S.: Incidence and prevention of infections and mastitis in heifers, Veterinary Life, 82, 476-482, 2007.

Parker, K. J., Compton, C., Anniss, F. M., Weir, A., Heuer, C., and Mc Dougall, S.: Subclinical and Clinical Mastitis in Heifers Following the use of a Teat Sealant Precalving, J. Dairy Sci., 90, 207-218, 2007.

PFHBiPM: Polish Federation of Cattle Breeders and Dairy Farmers: Rating Dairy Cattle, Warsaw, 2015.

Regulation of the Minister of Agriculture and Rural Development of the 5th July 2002: on detailed special veterinary conditions required for obtaining, processing, storage and transport of milk and milk products, Journal of Laws, 117, 7710-7718, 2002.

SAS: Guide for Personal Computers, ver. 9.2. SAS Inst. Inc., Cary, NC, USA, 2009.

Schaub, J., Friedli, K., and Wechsler, B.: Soft mats for boxes for lying for dairy cows, Taenikon, No. 529, 1999.

Schlueter, D.: Seperated manure as a badding, Elite, 5, 50-53, 2012.

Schrade, S., Zaehner, M., and Schaeren, W.: Bedding for dairy cows in box for lying, Compost and solids from the separation of liquid manure as an alternative to straw-manure mattress, Taenikom, No. 699, 2008.

Schwarz, M., Bonhotal, J., and Staehr, A. E.: Use of Dried Manure Solids as Bedding for Dairy Cows, Cornell Waste Management Institute, 9, 2010.

Sontheimer, A.: (No) secretly sick, New Agriculture, 3, 75-76, 2011.

Zaehner, M., Schrade, S., Schaeren, W., and Schmidtko, J.: New materials as litter in resting pens of dairy barns, Science Conference on Organic Agriculture, Taenikon, Band 2, 50-53, 2009a.

Zaehner, M., Schmidtko, J., Schrade, S., Schaeren, W., and Otten, S.: Alternative bedding materials in cubicle/boxes for lying, Bautagung Raumberg, Gumpenstein, 33-38, 2009b.

Ziemiński, R. and Juszczak, J.: Milk urea content as an indicator of protein:energy ratio in feed ration for dairy cows, Progress in Agricultural Sci., 3, 73-82, 1997. 